\title{
Rock mechanics investigations at Tummalapalle uranium mine of UCIL, AP, India
}

\author{
Ajay Ghade, KK Rao and KS Vijay Kumar \\ Uranium Corporation of India Ltd. \\ Tummalapalle, India \\ vijayucil@gmail.com
}

\author{
GD Raju, V Venkateswarlu and AY Bharath Kumar \\ National Institute of Rock Mechanics \\ Kolar Gold Fields, India \\ guntumadugu.raju@mail.mcgill.ca
}

\begin{abstract}
This paper presents all the rock mechanics studies carried out at UCIL-Tummalapalle mine, Andhra Pradesh. The rock mechanics investigations in this mine includes, optimization of pillar dimensions by numerical modeling, feasibility of hangwall lode mining at shallow depth, support design for deeper levels, instrumentation to monitor the strata for an experimental hang wall stope, monitoring of pore water pressure at underground crusher chamber and surface subsidence monitoring. The main aim is to benefit the mine immensely in improving extraction ratio and the safety levels from these rock mechanics studies.
\end{abstract}

Keywords—rock mechanics; numerical model; stoping, supports; crown pillar

\section{INTRODUCTION}

The Uranium Corporation of India Limited (UCIL) is operating an underground mine near Tummalapalle in YSR district, Andhra Pradesh, to mine the ore of Uraninite mineral / Pitchblende hosted by the dolomitic limestone. Geologically the area falls in the SW part of the "Cuddapah" basin .Tummalapalle Uranium mine $\left(14^{\circ} 18^{\prime} 36.6^{\prime \prime} \mathrm{N}\right.$ $14^{\circ} 20^{\prime} 20^{\prime \prime} \mathrm{N}: 78^{\circ} 15^{\prime} 16.57^{\prime \prime} \mathrm{E} 78^{\circ} 18^{\prime \prime} 3.33^{\prime \prime E}$ situated in the Cuddapah district of Andhra Pradesh, falls in the Survey of India toposheet No. $57 \mathrm{~J} / 3 \& 7$ and is about $12 \mathrm{~km}$. NNW of Pulivendula town.

Uranium mineralization occurring at Tummalapalle mine is of two lodes i.e. hang wall lode (average width $3.2 \mathrm{~m}$ ) and footwall lode (average width $2.5 \mathrm{~m}$ ), separated by 1.5 to $3 \mathrm{~m}$ thick lean zone. The ore body is uniform in its thickness and trend, with an average dip of $15^{\circ}$ due $\mathrm{N} 22^{\circ} \mathrm{E}$. The extent of the ore body is $5.6 \mathrm{~km}$ along the strike and $1 \mathrm{~km}$ along dip, with overburden depth ranging from $15 \mathrm{~m}$ to $275 \mathrm{~m}$. The depth of present mine workings are below $100 \mathrm{~m}$. The weathering zone (weathering grade W2) extends for 40 to 50 $\mathrm{m}$ below the surface. Three declines, $5 \mathrm{~m}$ in width and $3 \mathrm{~m}$ in height, along an apparent dip of 9o due NE, are being driven $15 \mathrm{~m}$ apart to work the two lodes at different levels. Various rock mechanics investigations are carried out at this mine to come out with optimum solution for better safety and extraction ratio.

\section{Geology And Geo Mining Conditions}

Uranium mineralization at Tummalapalle Uranium Mine is hosted by Vempalle dolomites of Papaghni group of
Cuddapah super group. Mineralization is of strata bound type, confined between two lithological units' viz., red Shale and massive limestone. The radioactive minerals present in the ore are pitchblende, coffinite and uranium titanium complex.

Uranium mineralization is occurring as two lodes in dolomite (impure siliceous, phosphatic, stromatolitic dolostone) and designated as Hang wall lode (width $3.2 \mathrm{mtr}$ ) and foot wall lode (width $2.5 \mathrm{mtr}$ ) separated by $1 \mathrm{mtr}$ to $3 \mathrm{mtr}$ lean zone.

The strike direction of the ore body is N680E- S680W, dipping towards $\mathrm{N} 220 \mathrm{E}$ with average dip amount of 150 . The dimension of the ore body is $5.6 \mathrm{~km}$ along the strike and $1 \mathrm{~km}$ along the dip with overburden depth ranging from $15 \mathrm{~m}$ to 275 mtr. Hang wall lode is more persistent in its thickness and grade than the Foot wall lode in entire strike length. The stratigraphy of Tummalapalle mine and bore hole section are furnished in Table I and Fig. 1 respectively.

TABLE I. STRATIGRAPHY OF MINE

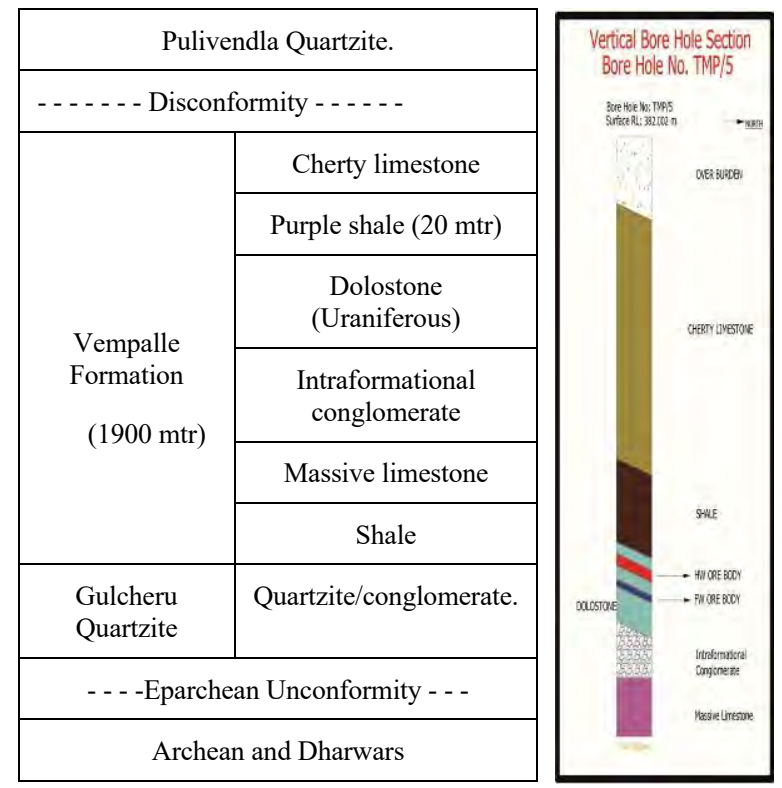

Fig.1. Stratigraphy and Borehole section 


\section{Method OF Mining}

Tummalapalle uranium mine is a highly mechanized underground mine which is developed with three set of declines $(5 \mathrm{~m} \times 3 \mathrm{~m})$ at $15 \mathrm{~m}$ interval, driven at 90 gradient in apparent dip direction in the ore body. The advanced strike drives (ASDs) of size $4.5 \mathrm{~m}(\mathrm{~W}) \times 3 \mathrm{~m}(\mathrm{H})$ are driven in strike direction from both service declines at vertical intervals of $10 \mathrm{~m}$. Levels are connected with the Ramps developed at 9o apparent dip with an interval of 120 metre. Mining of hangwall lode will be undertaken only after complete filling of mined out areas of footwall lode. Ore extraction (stoping) is carried by room and pillar method in Tummalapalle mine.

Stope blocks of dimension (120m Length X 39m width) will be developed by driving ramps at every $120 \mathrm{~m}$ interval between the rib pillars of $7 \mathrm{mtr}$ wide, which are left at $120 \mathrm{~m}$ interval for supporting the roof. After developing the ramps, stope drives will be developed on either side of the ramp up to the limit of the rib pillars. These stope drives will be interconnected by forming room and pillar of dimension $5.5 \mathrm{~m} \times 4.5 \mathrm{~m}$.

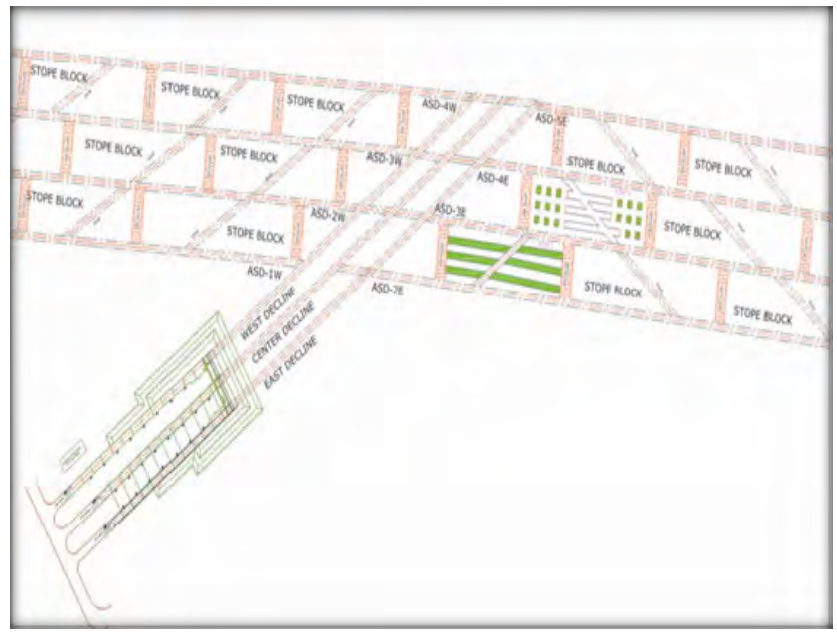

Fig. 2. Schematic diagram of underground mine development

Presently 18 levels have been developed in the foot wall lode on either side of the decline and are confined to foot wall lode only.

\section{ISSUES AT TUMMALAPALLE Mine}

\section{A. HW Lode Mining at Shallow Depth:}

Host for uranium mineralization at Tummalapalle mine is a dolomitic limestone. Carbonate content of Dolostone when exposed to water wash away forming the cavities. Intensity and occurrence of cavities progressively decreases with depth. It has been observed that up to a depth of $100 \mathrm{~m}$, roof protection requires addition support. Series of solution cavities due to the weathering were impedes the underground development. Solution cavities of shale and dolostone are shown in Fig.3.

\section{B. Pillar Dimensions for Final Stoping:}

Enormous samples were collected from Tummalapalle mine and analyzed its physico mechanical properties in the lab of National Institute of Rock Mechanics (NIRM), Kolar Gold field to assess the pillar dimension. Based on the properties obtained from the samples a Numerical model was prepared to assess the pillar dimensions.

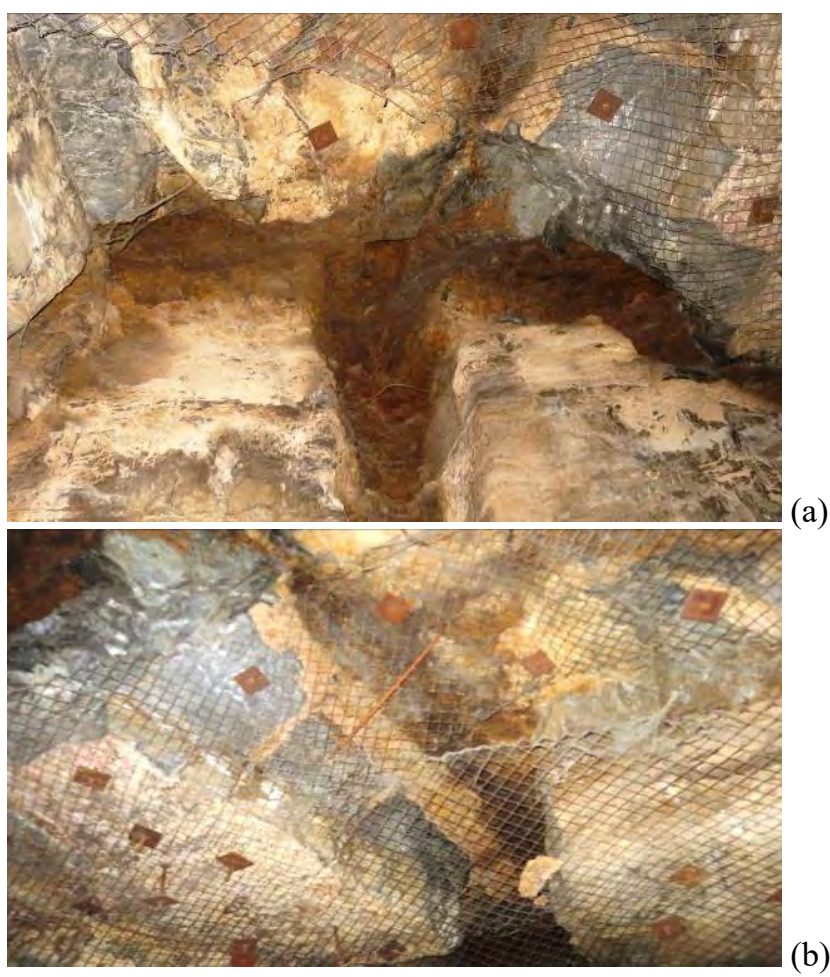

Fig. 3. Solution cavities of shale (a) and dolostone (b)

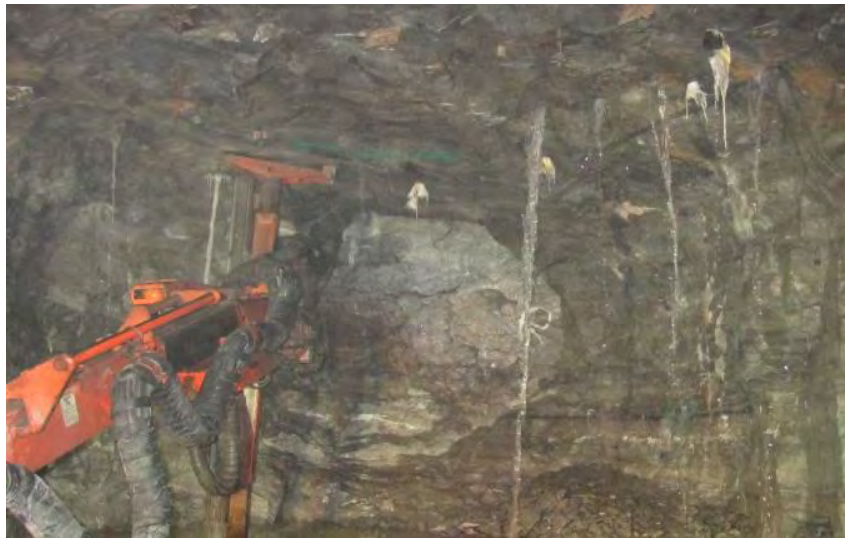

Fig. 4. water seepage from drill holes

\section{Shale Roof Problem:}

Lithologically, red shale (Ferruginous) is an argillaceous rock formed due to compaction of clay minerals (Mud). Major part of the reserves in Tummalapalle mine is confined to Hangwall lode which is capped by red shale with adverse physical properties on stability considerations. However, efforts are being made to assess the properties at different depth with an aim to recover Hangwall lode. Experimental hang wall drives and trial hang wall stope have been opened randomly at vertical depths of $70 \mathrm{mtr}, 90 \mathrm{mtr}, 100 \mathrm{mtr}$, and 
$120 \mathrm{mtr}$ to ascertain the ground conditions. The support design which is followed for supporting the dolostone has been practiced for Shale rock which is the roof for Hang wall lode. The following problems were encountered in the hangwall drive developments while supporting the roof (Fig. $4,7)$.

- Continuous heavy water seepage from the roof i.e. from Red Shale.

- Wash out of full column cement grout, due to pressure of seepage water.

- Collapsing of drilled holes constraining installation of Rock bolts.

- Collapsing of layers (50 $\mathrm{cm}$ transition zone) from the roof.

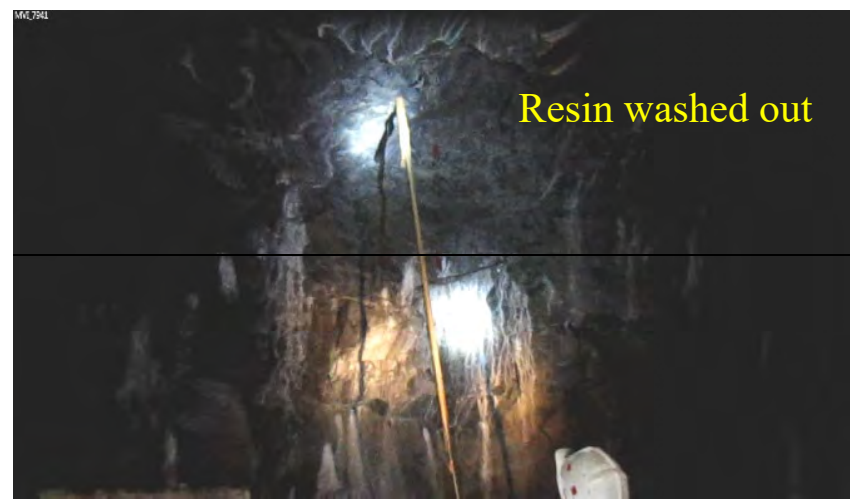

Fig. 5. Washed out resin capsule

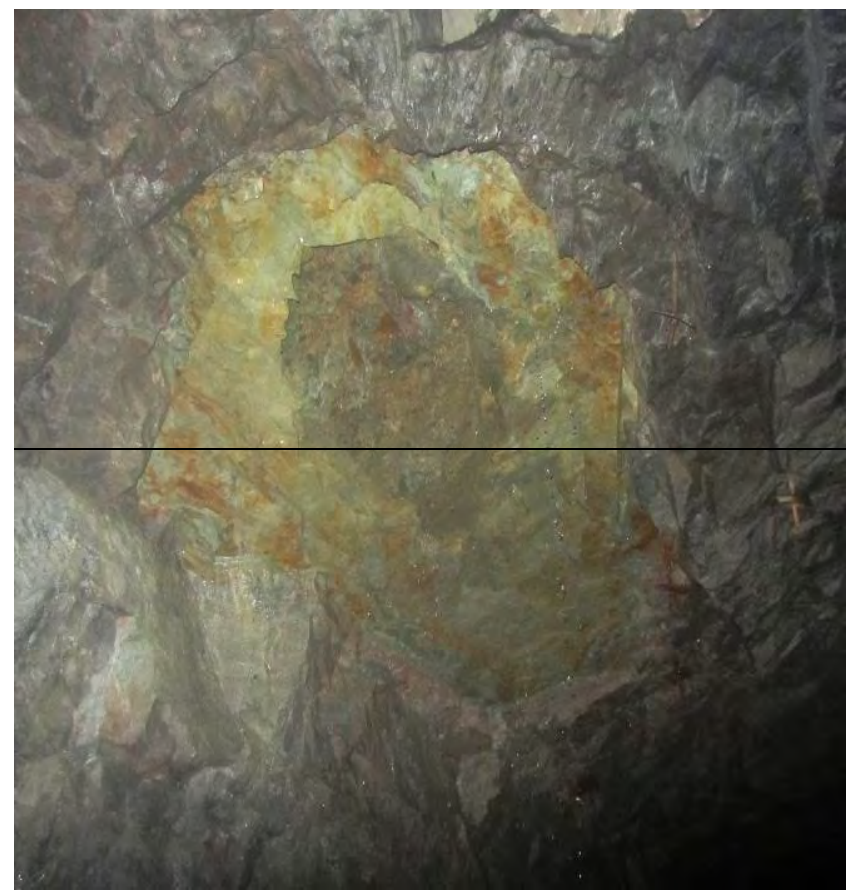

Fig. 6. Exposure of Shale

\section{Extraction Ratio vis-à-vis Safety Factor:}

1. Review of present pillar dimensions and optimization:
The present remnant pillar size is $4.5 \times 4.5 \mathrm{~m}$ square pillar. The rib pillar would be $7 \mathrm{~m}$ wide and the crown and sill pillars of $5 \mathrm{~m}$ thick. The factor of safety and the extraction ratio of the present pillar sizes is estimated and detailed below.

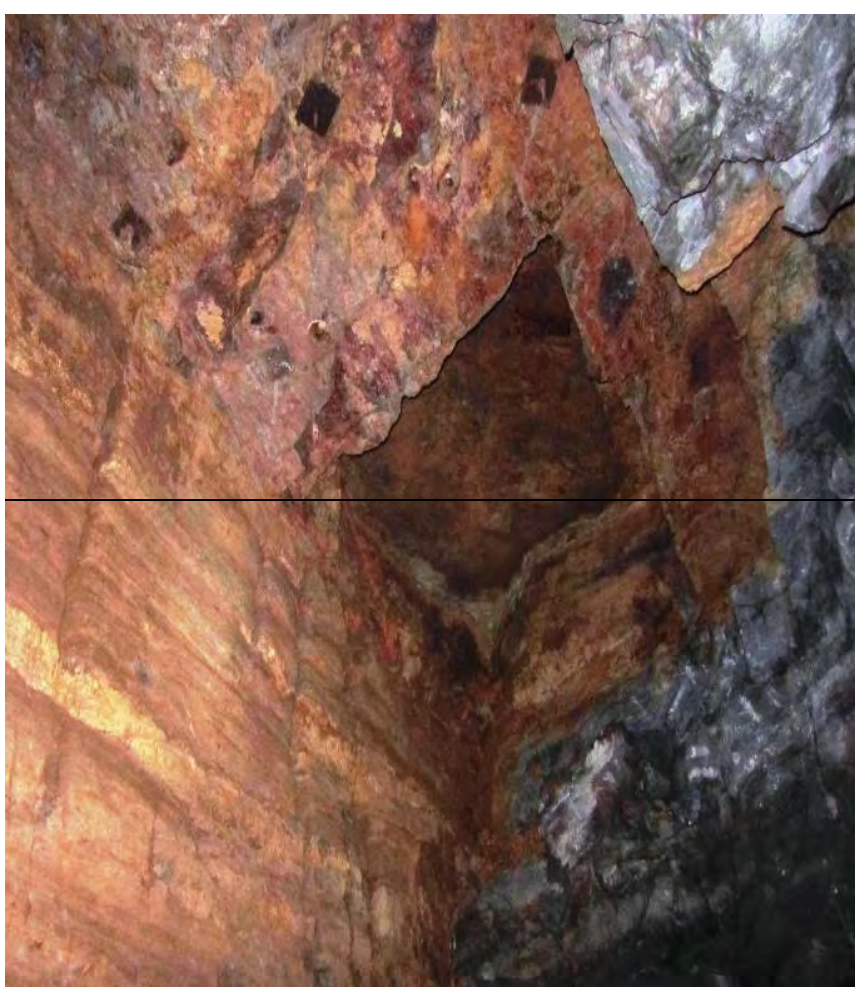

Fig. 7. Collapsing of layers

TABLE II. DETAILS OF EXISTING AND RECOMMENDED PILLAR DIMENSIONS

\begin{tabular}{|c|c|c|c|c|c|}
\hline Pillar & $\begin{array}{c}\text { Existing } \\
\text { Dimensions } \\
\text { (M) }\end{array}$ & FOS & $\begin{array}{c}\text { Recommende } \\
\text { d Dimensions }\end{array}$ & $\begin{array}{c}\text { FOS } \\
\text { Empirical }\end{array}$ & $\begin{array}{c}\text { FOS } \\
\text { Numerical }\end{array}$ \\
\hline $\begin{array}{c}\text { Remnant } \\
\text { Pillar }\end{array}$ & $4 . .5 \times 4.5$ & 4.97 & $4 \times 4$ & 4.08 & $4-6$ \\
\hline $\begin{array}{c}\text { Rib/Barrier } \\
\text { Pillar }\end{array}$ & 7.0 & 14.51 & 4.0 & 10.8 & $4-6$ \\
\hline $\begin{array}{c}\text { Sill/crown } \\
\text { Pillar }\end{array}$ & 5.0 & 13.46 & 4.0 & 11.85 & $3-5.5$ \\
\hline
\end{tabular}

2. Support design for deeper levels:

Relevant data required for the study was collected from the mine during the field visits. The rock mass of the deeper levels (beyond 10th Level) are classified. Representative Rock blocks were also collected from the underground, for determining physico-mechanical properties of these rocks in the laboratory at NIRM. Based on all these studies, the rock mass characterization was made, and the rock mass are classified to establish its quality for the stability of the workings during and after mining in these levels and to design the appropriate support system.

The average ' $Q$ ' and 'RMR' values estimated for the deeper levels is presented in Table III. 


\section{Feasibility of HW lode mining:}

The feasibility study of mining of the HW lode between 2nd and 6th levels was carried out. As part of this study, classification of the rockmass was also carried out between 2nd and 6th levels to study its quality and evaluation of the mine ability of HW load under shallow depth up to $50 \mathrm{~m}$. Numerical modeling for feasibility of HW load mining using the Rock Mass properties already determined is also under progress.

\section{Instrumentation:}

Stopping is being carried out at 5E HW lode panel, on experimental basis. To understand the strata behaviour during and after stopping operations, the above panel is instrumented using variety of instruments such as Stress Cells, Load Cells, Extensometers to monitor the stress in the remnant and barrier pillars, load on the rock bolt support sytem and deformation in the roof and walls. The location and the type of instruments installed in the above panel is shown in Fig.8. data is being analyzed to understand the strata behaviour during and after depillaring which will enable to plan for effective strata control program in the future panels.

TABLE III. AVERAGE Q AND RMR VALUES

\begin{tabular}{|c|l|c|c|}
\hline SI No. & \multicolumn{1}{|c|}{ Location } & $\begin{array}{c}\text { Average } \\
\text { RMR }\end{array}$ & Average Q \\
\hline 1 & $\begin{array}{l}\text { ASD 5E Hangwall Ramp down } \\
(40 \mathrm{~m} \text { inbye) }\end{array}$ & 44.20 (Fair) & 2.86 (Poor) \\
\hline 2 & ASD 5E P1 E2 (60 m inbye) & 45.85 (Fair) & 2.77 (Poor) \\
\hline 3 & ASD 5E P1 E3 (30 m inbye) & 44.50 (Fair) & 3.35 (Poor) \\
\hline 4 & ASD 5E P1 W2 (13 m inbye) & 41.60 (Fair) & 2.26 (Poor) \\
\hline 5 & $\begin{array}{l}\text { ASD 6E Hangwall drive west } \\
\text { (70 m inbye) }\end{array}$ & 55.25 (Fair) & 5.67 (Fair) \\
\hline 6 & ASD 1E (130 m inbye) & 34.50 (Poor) & 2.94 (Poor) \\
\hline 7 & ASD 2E (150 m inbye) & 33.50 (Poor) & 2.50 (Poor) \\
\hline 8 & $1 \mathrm{E}$ to 3E (120 m decline) & 41.62 (Fair) & 3.56 (Poor) \\
\hline
\end{tabular}

All the instruments are being monitored regularly and the

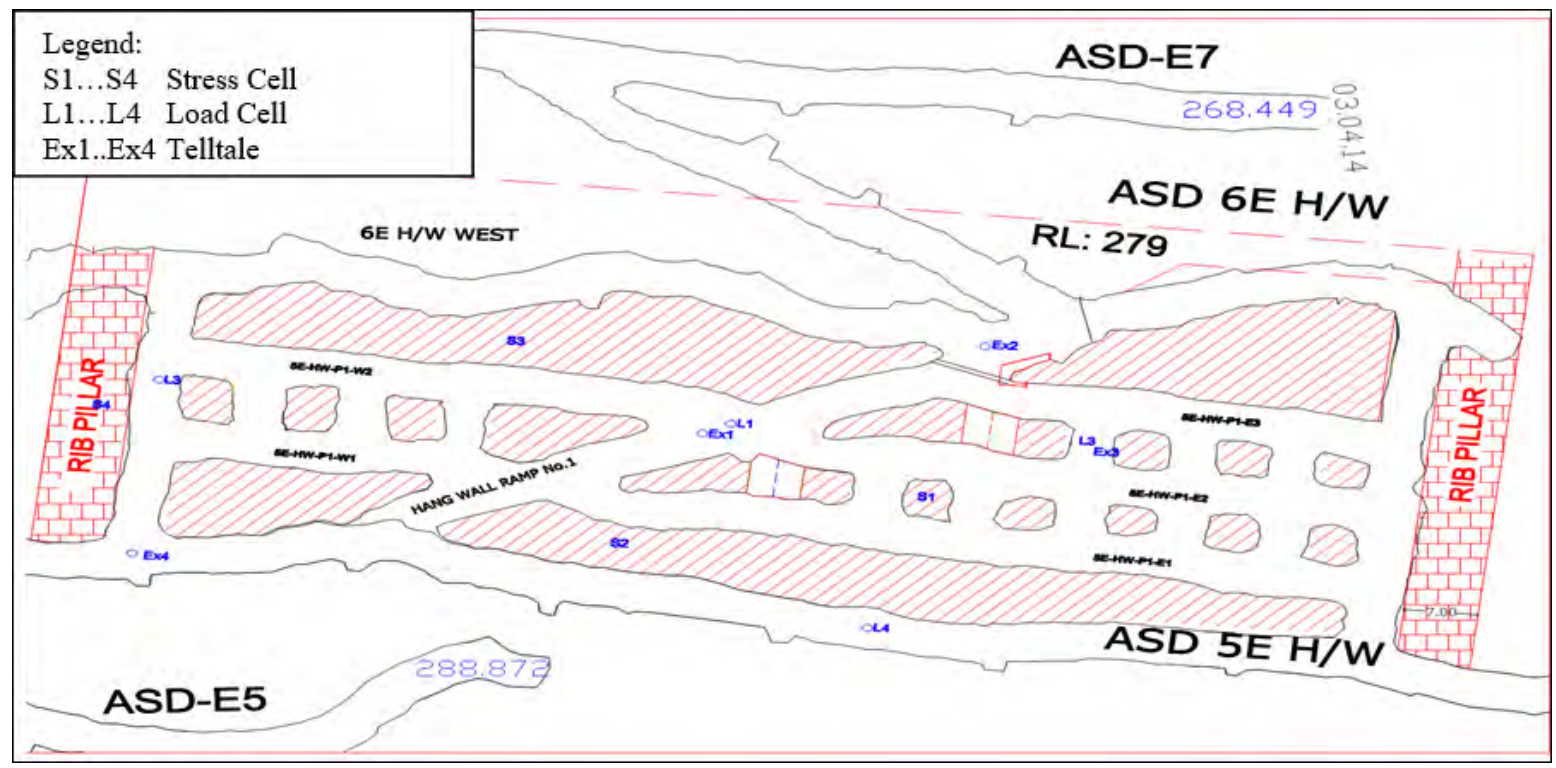

Fig. 8. Location and type of Instruments installed at 5E HW panel.

\section{CONCLUSIONS}

Extensive problem centric rock mechanics investigations have been carried out at Tummallapalle Uranium Mine such as optimization of pillar sizes, feasibility of HW lode mining, support design for deeper levels, instrumentation for strata behavior monitoring. Some new supporting items like friction bolts and welded mesh are being used for additional supports in the weathered zones of the mine, which has proven beneficial in safe mining practices. Moreover, leaving of $50 \mathrm{~cm}$ dolostone roof below the transition zone has improved the efficiency of safe extraction of Ore. Some of the studies were already implemented and investigations on some are ongoing. The mine has immensely benefited from the above rock mechanics studies and improved safety and productivity.

\section{ACKNOWLEDGEMENTS}

The authors express their gratitude to CMD, UCIL and Director NIRM for permitting to submit this paper which is beneficial for the mining society. Thanks are also due to the officers of UCIL, Tummalapalle mine for their co-operation during the rock mechanics investigations. We also would like to express our thankfulness to Mr. Udaya Kumar and Dr.L.G.Singh, Scientists, NIRM for their able contributions in determining the rock physico-mechanical properties in lab and rock mass classification in the field respectively. 